\title{
Research on the Relationship among Technology Sources, Learning Modes and Innovation Performance of Technical SMEs of Tianjin
}

\author{
Zhao Geng ${ }^{1}$ Li Zibiao $^{1}$ MaJie $^{1}$ \\ 1. School of Economics and Management, Hebei University of Technology, China, 300401
}

\begin{abstract}
Due to the characteristics of high technology and knowledge intensity in Technical small and medium-sized enterprises (SME), the research on technical resources, technology development and learning mode of Technical SME and the exploration of acting mechanism and innovation performance, are theoretically important to guide technical SME development. In this paper, the survey is taken with respect to tech SMEs in Tianjin, through research on the implementation of their projects with Innovation Fund analyzed their sources of technology and types of learning model and established a relationship model of their sources of technology, learning modes and innovative performance. We have accomplished an empirical research verified the proposed hypothesis and therefore got useful conclusions.
\end{abstract}

Keywords-Technical Small and Medium-sized Enterprise (SME), Source of Technology, Learning Mode, Innovation Performance, Relationship

\section{INTRODUCTION}

Among the developed countries such as the U.S., U.K., Germany, as same as developed areas in Southeastern China, the development of technical SMEs has been attached with great importance. At present, Tianjin has formed a group of technical SMEs with property rights and key technology, cultivated a set of new products with high technology and strong competition, created a large number of star companies with billions sales revenue, and laid a solid foundation for achieving breaking development. There is no doubt that technical SMEs' development has become the representation for economic growth and important promotion in Tianjin. Analyzing the relationship among source of technology, learning mode and innovation performance of technical SME in Tianjin have great significance to understand the pattern of their development.

\section{CONCEPT MODEL}

A. Source of Technology, Learning Mode and Innovation Performance

Enterprise's technology sources of technology innovation fund project are relatively regularly, and can be roughly divided into two parts: from outside of the enterprise and from inside of the enterprise. The technology comes from outside of the enterprise can be divided into three types by different ways to obtain technology: all outsourcing $\mathrm{R} \& \mathrm{D}$, purchase patents or proprietary technology and purchase technology shares. From inside of the enterprise is its own technology, according to different $R \& D$ participants were divided into two types: independent R\&D and cooperative R\&D. Cooperative $R \& D$ could have more partners, such as universities, independent research institutions, businesses, suppliers, and customers, etc. According to different regions, the partners are divided into two types (marked by administrative divisions): local and non-local. On this basis, this study proposes theoretical framework of source of technology, learning model and technology innovation performance, as shown in Figure 1. 


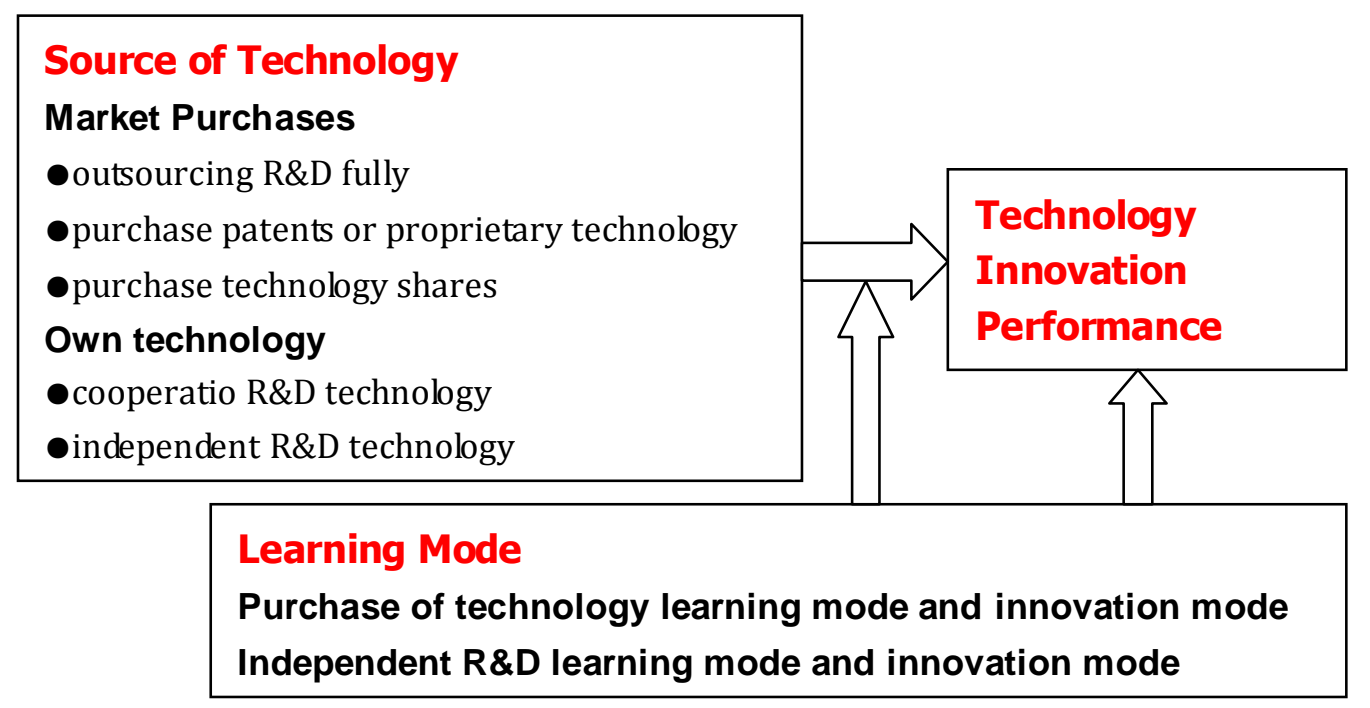

Fig 1. Theoretical Framework of Source of Technology, Learning Model and Technology Innovation Performance

\section{B. Assumptions about the Relationship among Source of Technology, Learning Mode and Innovation Performance}

Existing literature shows that get external technology means absorption of existing external technical and knowledge. In addition, if the corporate lacks of technology outsourcing-related knowledge, it will not be able to communicate with suppliers use similar terms of reference and other familiar terminology framework, and thus might mislead collaborators or to give them unrealistic expectations. Finally, enterprise lacks of technical capacity in relevant field, enterprise will not or inefficiently be benefit from technology transfer and technology licensing, for exogenous knowledge is usually more difficult to understand and explain. Organizational learning and knowledge base are positively related. Means that enterprise need to have a certain level of technical knowledge in order to benefit from the technology that other enterprises have founded. These arguments mean internal $R \& D$ investment can enhance the absorption, transformation and using for external technology which from R\&D contracts. Within a certain period total, internal $R \& D$ investment is limited by its own R\&D level, thus when buying more patented technology / proprietary technology than a certain amount, but there is no capacity to absorb and utilize them, it will limit the secondary development of these technologies, and affecting the innovation performance. Thus, we found that the level of internal $R \& D$ positively regulate the relationship between $R \& D$ outsourcing and innovation performance. Therefore, we assume that,

$\mathrm{Hb} 1$ : Outsourcing $\mathrm{R} \& \mathrm{D}$ fully enterprise, against technological innovation;

Hb2: Purchase patents or proprietary technology enterprise, against technological innovation;

Hb3: Purchase technology shares beneficial to technological innovation of enterprises;
Hr1: Enterprise's independent technology R\&D has a certain extent of inhibition to its technology innovation performance;

H11: R\&D investment level has positive impact on technological innovation performance;

H12: Using the purchase of technology learning mode to learn the purchased technology and re-innovation, innovation performance is better than the purchase of technology learning mode to learn independent $R \& D$ technology or independent $R \& D$ learning mode to learn purchased technology.

HI3: Using independent R\&D learning mode to learn the independent R\&D technology and re-innovation, innovation performance is better than independent $R \& D$ learning mode to learn purchased technology and the purchase technology learning mode to learn independent R\&D technology.

Hr2: R\&D cooperation with enterprises, university, research institutions etc. beneficial to technology innovation of enterprises.

\section{DATA AND INDICATORS}

\section{A. Learning Model}

Six indicators are set in independent R\&D learning mode. 
TABLE I INDEPENDENT R\&D LEARNING MODE AND THE PURCHASE OF TECHNOLOGY LEARNING MODE INDICATOR

\begin{tabular}{|c|c|c|}
\hline Variables & Indicators & Index value \\
\hline \multirow{6}{*}{$\begin{array}{l}\text { Learn of } \\
\text { independent } \\
\text { R\&D learning } \\
\text { mode }\end{array}$} & Establish employee feedback system & $\begin{array}{l}\text { Enterprise has feedback system }=1 \\
\text { Otherwise }=0\end{array}$ \\
\hline & Existence of functional integration & $\begin{array}{l}\text { Enterprise has functional integration=1; } \\
\text { Otherwise }=0\end{array}$ \\
\hline & $\begin{array}{l}\text { Weakening functions between } \\
\text { different departments }\end{array}$ & $\begin{array}{l}\text { No significant difference between } \\
\text { departments }=1 \text {; Otherwise }=0\end{array}$ \\
\hline & $\begin{array}{l}\text { Different professional backgrounds } \\
\text { working together }\end{array}$ & $\begin{array}{c}\text { Enterprise has different professional } \\
\text { backgrounds working together }=1 \text {; Otherwise }=0\end{array}$ \\
\hline & Quality discussion group & $\begin{array}{l}\text { Enterprise has quality discussion group }=1 \text {; } \\
\text { Otherwise }=0\end{array}$ \\
\hline & $\begin{array}{l}\text { Employees independent working } \\
\text { group }\end{array}$ & $\begin{array}{l}\text { Enterprise has employees independent working } \\
\text { group }=1 \text {; Otherwise }=0\end{array}$ \\
\hline \multirow{3}{*}{$\begin{array}{l}\text { Learn of the } \\
\text { purchase of } \\
\text { technology } \\
\text { learning mode }\end{array}$} & $\begin{array}{l}\text { The proportion of the year's } R \& D \\
\text { revenues accounted for annual } \\
\text { turnover }\end{array}$ & $\begin{array}{l}\text { Investment in } \mathrm{R} \& \mathrm{D} \text { ratio exceeds } 10 \%=1 \text {; } \\
\text { Otherwise }=0\end{array}$ \\
\hline & $\begin{array}{l}\text { The proportion of college degree or } \\
\text { above professional and technical } \\
\text { personnel accounting for the total } \\
\text { number of employees }\end{array}$ & $\begin{array}{l}\text { The proportion exceeds } 30 \%=1 \text {; } \\
\text { Otherwise }=0\end{array}$ \\
\hline & $\begin{array}{l}\text { Collaboration with universities / } \\
\text { independent research institutions }\end{array}$ & $\begin{array}{l}\text { Collaboration with universities / independent } \\
\text { research institutions }=1 \text {; } \\
\text { Otherwise }=0\end{array}$ \\
\hline
\end{tabular}

B. Sources of Technical

In this study, sources of technical were divided into two types: from within the enterprise and from outside the enterprise, indicators in Table 2.

TABLE II TECHNOLOGY SOURCE INDICATOR

\begin{tabular}{|c|c|c|}
\hline Variables & Indicators & Index Value \\
\hline \multirow{3}{*}{$\begin{array}{l}\text { Purchase of } \\
\text { technology }\end{array}$} & $\begin{array}{l}\text { Purchase of patents or } \\
\text { proprietary technology }\end{array}$ & purchase patents or proprietary technology $=1$; Otherwise $=0$ \\
\hline & Outsourcing R\&D fully & $\mathrm{R} \& \mathrm{D}$ outsourcing fully $=1$; Otherwise $=0$ \\
\hline & Purchase technology shares & Enterprise purchase technology shares $=1$; Otherwise $=0$ \\
\hline $\begin{array}{l}\text { Enterprise } \\
\text { own } \\
\text { technology }\end{array}$ & Independent R\&D & Enterprise independent $\mathrm{R} \& \mathrm{D}=1$; Otherwise $=0$ \\
\hline \multirow{5}{*}{$\begin{array}{l}\text { R\&D from } \\
\text { product, } \\
\text { study and } \\
\text { research }\end{array}$} & $\begin{array}{l}\text { Local universities /independent } \\
\text { research institutions }\end{array}$ & $\begin{array}{l}\text { Collaboration with local universities/independent research } \\
\text { institutes }=1 \text {; Otherwise }=0\end{array}$ \\
\hline & $\begin{array}{l}\text { Universities } \\
\text { /independent research } \\
\text { institutions in Beijing }\end{array}$ & $\begin{array}{l}\text { Enterprise in Tianjin Collaboration with Beijing } \\
\text { universities/independent research institutes }=1 \text {; Otherwise }=0\end{array}$ \\
\hline & $\begin{array}{l}\text { Universities /independent } \\
\text { research institutions in other } \\
\text { areas of the country }\end{array}$ & $\begin{array}{l}\text { Enterprise in Tianjin collaboration with } \\
\text { Universities/independent research institutions in other areas of } \\
\text { the country }=1 \text {; Otherwise }=0\end{array}$ \\
\hline & $\begin{array}{l}\text { Foreign universities } \\
\text { /independent research } \\
\text { institutions }\end{array}$ & $\begin{array}{l}\text { Enterprise collaboration with foreign universities/independent } \\
\text { research institutions }=1 \text {; Otherwise }=0\end{array}$ \\
\hline & Other enterprises & Enterprise collaboration with others $=1$; Otherwise $=0$ \\
\hline
\end{tabular}

C. Innovation Performance

Innovation performance in this study, refers to obtained from technical innovation fund projects, generated by technological change (Chen Jin, Chen 
Yu-Fen, 2006), indicators to measure with lower production costs, improve product quality, new patents and new products because of technology improvements or updates. As table 3 shows.

TABLE III INNOVATION PERFORMANCE INDICATOR

\begin{tabular}{ll}
\hline Variables & Indicators \\
\hline \multirow{3}{*}{ Patents } & The number of patent applications \\
\cline { 2 - 2 } & The number of granted patents \\
\cline { 2 - 2 } & The number of invention patents \\
\hline \multirow{3}{*}{ Others } & Improve product quality \\
\cline { 2 - 2 } & R\&D of new products \\
\hline
\end{tabular}

IV. METHOD

We used clustering analysis of SPSS software to analyze learning mode of the samples enterprise. In this study, we used quartering method analysis the of enterprise , learning mode be divided into four types: 1, Purchase of technology learning mode; 2, Independent R\&D technological learning mode; 3, Purchase of technology learning mode/independent R\&D technological learning mode; 4, Other learning modes, namely the control group. According to the classification results, enterprises are divided into four categories, assigned to them for 0 or 1 , and finally regression analysis on learning mode, sources of technology and innovation performance, to examine the theoretical assumptions relationship and analyze survey data in Tianjin. Reliability test of the learning mode results show that, the sample data in an acceptable level of 0.001 , indicating a good consistency of test results, stability and reliability.

\section{EMPIRICAL ANALYSIS AND RESULTS DISCUSSION}

We use the Tianjin data to verify the theoretical assumptions, and the results as follows:

TABLE IV THE RESEARCH HYPOTHESIS TEST RESULTS SUMMARIZE

\begin{tabular}{ll}
\hline \multicolumn{1}{c}{ Research hypothesis } & Support or not \\
\hline $\mathrm{Hb} 1:$ & Support \\
\hline $\mathrm{Hb} 2:$ & Support \\
\hline $\mathrm{Hb} 3:$ & Support \\
\hline $\mathrm{Hr} 1:$ & Support \\
\hline $\mathrm{H} 11:$ & Support \\
\hline $\mathrm{H} 12:$ & Support \\
\hline $\mathrm{H} 13:$ & Support \\
\hline $\mathrm{Hr} 2:$ & Partially supported \\
\hline
\end{tabular}

\section{CONCLUSIONS}

Outsourcing R\&D fully enterprise, single source of technology, single learning ability of external technology, weak foundation of internal knowledge accumulation. Due to the simple use of one technology source caused the contact with external resources is narrow, and open span is not enough. Similarly, using purchase patents / proprietary technology source only also exist path dependency problem, the purchase technical require enterprises have the corresponding absorption capacity, long-term purchase patents / proprietary technology source alone, other innovative capabilities and resources are not accumulated, not conducive to the long-term development and innovation.

Technology from "outsourcing R\&D fully" mode, its performance level is lower than the average performance level of sample, explained the way of technology source "outsourcing R\&D fully" not conducive to technological innovation, assuming $\mathrm{Hb} 1$ has been supported; Purchase patents or proprietary technology, its performance level is lower than the average performance level of sample, explain of this technology source mode not conducive to technological innovation, Therefore, assuming $\mathrm{Hb} 2$ has been supported; Purchase technology shares mode, its performance is higher than the average performance of sample, explained that this model have significant promoting for technological innovation of enterprises, assuming $\mathrm{Hb} 3$ has been supported; Sample enterprise who using independent $R \& D$, its performance is lower than the average performance, explained that independent $\mathrm{R} \& \mathrm{D}$ might have some inhibitory to technological innovation.

When enterprises use the purchase of technology learning mode, their technology source is also obtained by way of purchase, and performance was significantly better than the other sources; when enterprises use independent $\mathrm{R} \& \mathrm{D}$ learning mode, the source of technology is mainly independent $\mathrm{R} \& \mathrm{D}$ research, innovation performance significantly better than other techniques sources.

\section{REFERENCES}

[1] Lundvall B A. National systems of innovation: towards a theory of innovation and interactive learning. London: Pinter, 1992.

[2] Paul Romer. Endogenous Technological Change [J]. Journal of Political Economy, 1990, 98 (5); 71-102.

[3] G. M. Grossman and E. Helpman. Comparative advantage and long run growth $[\mathrm{J}]$. American Economic Review, 1990, 80: 796-815.

[4] Christensen, J. L. , Lundvall, B. A (eds), 2004. Product Innovation , Interactive Learning and Economic Performance. Elsevier Ltd.

[5] Lin Hsing-er, MCDONOUGH III E F. Investigating the role of leadership and organizational culture in fostering innovation ambidexterity $[\mathrm{J}]$. IEEE Transactions On Engineering Management, 2010, 58: 497-509 